\title{
Prolactin release during the estradiol-induced LH surge in ewes: modulation by progesterone but no evidence for prolactin-releasing peptide involvement
}

\author{
D C Skinner and A Caraty ${ }^{\mathbf{1}}$ \\ Department of Zoology and Physiology, University of Wyoming, Laramie, Wyoming 82071, USA \\ ${ }^{1}$ Institute National de la Recherche Agronomique, Unite Mixte de Researches Physiologie de la Reproduction et des Comportements, Nouzilly, France \\ (Requests for offprints should be addressed to D C Skinner; Email: DCS@uwyo.edu )
}

\begin{abstract}
An estradiol-induced prolactin surge accompanies the LH surge in several species, including sheep. However, the neural mechanisms underlying this surge remain poorly understood. A first study on estradiol- and progesteronetreated ovariectomized ewes examined whether the prolactin surge, like the LH surge, is sensitive to progesterone. Our data clearly showed that the estradiol-induced prolactin surge in the ewe is blocked by continuous exposure to progesterone and, importantly, that this blockade is overcome by pretreatment with the progesterone receptor antagonist, RU486. In a second study, we established that
\end{abstract}

the generation of the prolactin surge is not dependent on the co-secretion of a prolactin-releasing peptide in the hypophyseal portal blood or cerebrospinal fluid. The neuronal pathways targeted by estradiol and progesterone to modulate prolactin secretion at the time of the $\mathrm{LH}$ surge remain to be identified. Importantly, it has not been established whether there is any overlap in the neuronal systems generating the gonadotropin-releasing hormone and prolactin surges.

Journal of Endocrinology (2003) 177, 453-460

\section{Introduction}

At the time of the spontaneous or estradiol-induced luteinizing hormone (LH) surge, a concomitant prolactin surge has been reported in several species, including rats (Arbogast \& Ben-Jonathan 1988), sheep (Campbell et al. 1990, Anderson et al. 2001) and women (Djahanbakhch et al. 1984, Gonen \& Casper 1990). Recent studies in rats have indicated that this prolactin surge may be involved in luteolysis of the preceding corpus luteum (Gaytan et al. 1998, 2000, Bowen \& Keyes 1999, Bowen et al. 2000). Thus, the preovulatory prolactin surge may play a critical role in fertility, at least in rats. However, unlike the $\mathrm{LH}$ surge, there is a paucity of information on the prolactin surge.

Studies in sheep suggest that estradiol does not directly target the gonadotropin-releasing hormone (GnRH) neuron. Specifically, only estradiol microimplants placed in the ventromedial nucleus, where there are no $\mathrm{GnRH}$ neurons, are effective in inducing a GnRH surge (Caraty et al. 1998). Microimplants placed in the preoptic area, where GnRH neurons are predominantly located, are ineffective (Caraty et al. 1998). Immunocytochemical studies in sheep suggest that GnRH neurons do not possess the $\alpha$ estradiol receptor (Herbison et al. 1993, Lehman \& Karsch 1993). In light of these data, it has been suggested that an interneuronal system(s) plays a critical role, but its precise identity remains unknown (Herbison et al. 1993, Lehman \& Karsch 1993). It is possible that this interneuronal system may be shared by, or influence, those neurons responsible for generating the prolactin surge. Indeed, the ability of dopamine to alter both $\mathrm{LH}$ and prolactin secretion in the rat has led to the suggestion that some regulatory neural elements may be shared between different hormone systems (Fink 1988). We have recently reported that, in the ovine brain, all progesterone receptorexpressing cells also express estrogen receptors, suggesting that these two steroids act on overlapping neuronal pathways (Dufourny \& Skinner 2002). In sheep, progesterone inhibits tonic GnRH secretion (Skinner et al. 1998) and it powerfully blocks the estradiol-induced GnRH surge (Kasa-Vubu et al. 1992, Richter et al. 2002). Thus, if there is overlap between the neuronal systems generating the GnRH and prolactin surges then we hypothesized that progesterone would also block the estradiol-induced prolactin surge and this blockade would be overcome by the progesterone receptor antagonist, RU486. The first objective of our study addressed this hypothesis.

The neural pathways targeted by the ovarian steroids to generate the prolactin surge in the ewe remain unidentified but it is possible that the final endpoint is a recently identified peptide, prolactin-releasing peptide 
(PrRP), which occurs as a 31 amino acid, PrRP31, or is cleared to a 20 amino acid, PrRP20 (Hinuma et al. 1998). Recent studies in rats have suggested that this peptide may play a role in the generation of the preovulatory prolactin and, possibly, LH surges (Hizume et al. 2000). However, much controversy surrounds this peptide. Although some studies suggest that PrRP stimulates prolactin release during in vitro (Hinuma et al. 1998, Samson et al. 1998) and in vivo (Matsumoto et al. 1999b) studies, other investigations have revealed little or no effect (Jarry et al. 2000, Seal et al. 2000, Curlewis et al. 2002). Moreover, little or no immunoreactive PrRP has been detected in the external zone of the median eminence in the rat, suggesting that PrRP is not released into the hypophyseal portal system (Maruyama et al. 1999, Morales et al. 2000). To investigate the in vivo release of this peptide further, our second objective was to establish whether PrRP was detectable in hypophyseal portal blood at the time of the estradiol-induced prolactin surge. A few studies have also shown that intracerebroventricular administration of PrRP may affect several endocrine systems (Seal et al. 2000, 2002). Since PrRP terminals have been observed in the paraventricular nucleus, which is located adjacent to the third ventricle, it is plausible to speculate that some PrRP may enter cerebrospinal fluid (CSF). Thus, the final objective of this study was to determine whether PrRP was detectable in the CSF at the time of the estradiol-induced prolactin surge.

\section{Materials and Methods}

\section{Animals}

Sexually mature Ile-de-France or Dorset horn ewes were ovariectomized 1 month prior to experimentation and a $10 \mathrm{~mm}$ silicone elastomer $17 \beta$-estradiol implant was inserted subcutaneously at the time of ovariectomy. Ewes were housed in rooms with natural photoperiod, allowed free access to water and fed daily with hay, straw and corn. All procedures were carried out in accordance with Home Office License No. PPL 30/1670 and authorization A37801 of the French Ministry of Agriculture.

\section{Does progesterone block the estradiol-induced prolactin surge?}

The experimental design is shown in Fig. 1. Two progesterone-releasing intravaginal implants (CIDR; Pharmacia and Upjohn, Kalamazoo, MI, USA) were inserted for 10 days to simulate the natural luteal phase in all 18 ewes. At the time of progesterone implant removal, new CIDRs were inserted immediately into 12 ewes of which six (RU486 group) were injected with $100 \mathrm{mg}$ RU486 dissolved in $10 \mathrm{ml}$ vehicle (10\% alcohol in peanut oil) and six (P-block group) received vehicle only. The remaining six ewes (control group) were injected with

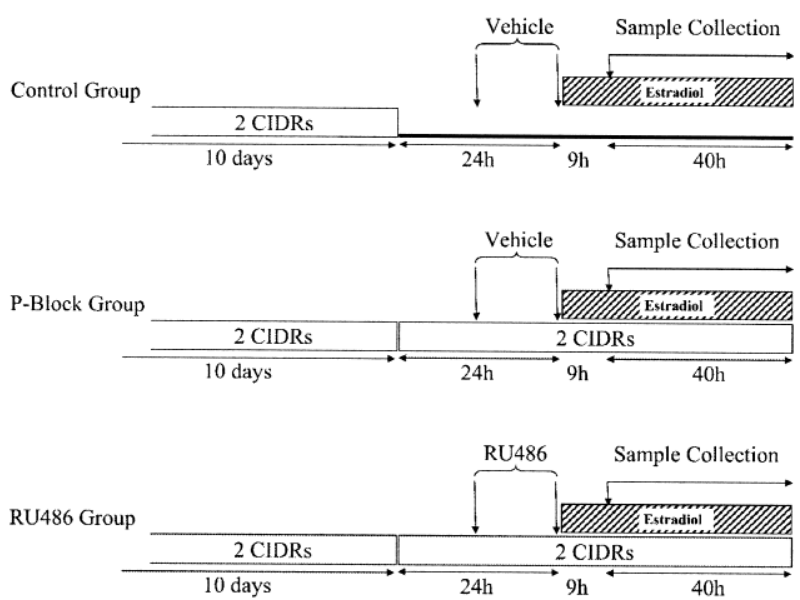

Figure 1 Experimental design.

vehicle only. RU486 and vehicle injections were made again $12 \mathrm{~h}$ and $24 \mathrm{~h}$ later. After the last RU486/vehicle injection, estrogen concentrations were raised in all ewes to peak follicular phase levels by subcutaneous insertion of four $3 \mathrm{~cm} \mathrm{17 \beta -estradiol} \mathrm{implants} \mathrm{(Goodman} \mathrm{et} \mathrm{al.} \mathrm{1981).}$ Blood samples were collected every $2 \mathrm{~h}$ for $40 \mathrm{~h}$, starting $9 \mathrm{~h}$ after insertion of the $3 \mathrm{~cm}$ estradiol implants. Prolactin concentrations were determined in a single assay using a previously described radioimmunoassay (Kann 1971). The intra-assay coefficient of variation and assay sensitivity were $6 \%$ and $1.0 \mathrm{ng} / \mathrm{ml}$ respectively.

\section{Is PrRP released into CSF at the time of the prolactin surge?}

Ewes $(n=4)$ had a cannula implanted in the third cerebroventricle (Skinner et al. 1995, 1997) and were treated with steroids according to the protocol used for the control ewes in the first experiment but no peanut oil vehicle was administered. CSF and jugular blood samples were collected as described in detail previously (Skinner et al. 1995, 1997). After assaying jugular plasma samples for prolactin, selected jugular plasma and CSF samples were assayed for PrRP. One sample was analyzed from each ewe for each phase of the prolactin surge (early: 9-13 h; mid: 15-21 h; late: $25-31 \mathrm{~h}$; all relative to the time of estradiol insertion).

Is PrRP released into hypophyseal portal blood at the time of the prolactin surge?

Ewes $(n=5)$ were subjected to hypophyseal portal system surgery (Caraty \& Locatelli 1988) and treated with steroids according to the protocol used for the control ewes in the first experiment but no peanut oil vehicle was administered. Hypophyseal portal blood and jugular blood samples were collected as described in detail previously (Skinner et al. 1995, 1997). To reduce peptide degradation, bacitracin $\left(0.5 \mathrm{ml} 3 \times 10^{-3} \mathrm{M}\right)$ was added to the collection tubes, which were held on ice during the collection. After assaying jugular plasma samples for prolactin, selected 

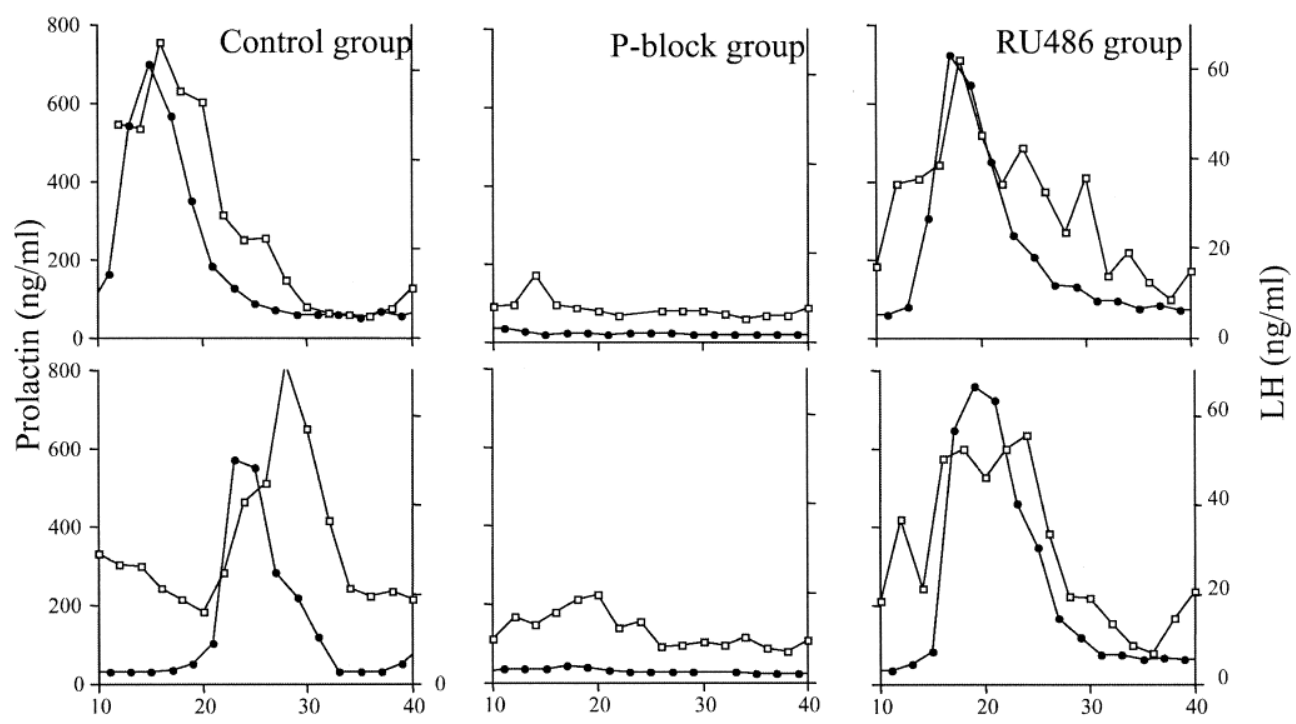

Time (h) from insertion of $17 \beta$-estradiol

Figure 2 Representative results from two ewes in each of the three treatment groups. Progesterone blocked both the $\mathrm{LH}(\bullet)$ and prolactin $(\square)$ surges and this blockade was overcome by pretreatment with RU486. LH data were reported upon previously (Skinner et al. 1999).

hypophyseal portal blood plasma samples corresponding to different phases of the estradiol-induced prolactin surge were analyzed for PrRP. One sample was analyzed from each ewe for each phase of the prolactin surge (pre: 9-13 h; early: 13-15 h; mid: 15-21 h; late: 21-29 h; all relative to the time of estradiol insertion). As PrRP was not detectable in jugular plasma in the previous study, jugular samples in this study were not assayed for PrRP.

\section{$\operatorname{Pr} P$ assay}

Plasma and CSF samples were analyzed for PrRP as previously described (Matsumoto et al. 1999a). Briefly, $1.5 \mathrm{ml}$ plasma or CSF was acidified by adding $4 \%$ acetic acid $(4.5 \mathrm{ml})$ and centrifuged at $25000 \mathrm{~g}$ at $4{ }^{\circ} \mathrm{C}$ for $30 \mathrm{~min}$. The supernatant was applied to a Sep-Pak C-18 cartridge (Waters, Milford, MA, USA), washed with $10 \mathrm{ml}$ water and then eluted with $4 \mathrm{ml}$ acetic acid: ethanol:water (4:86:10). Samples were then concentrated using a vacuum centrifuge (Thermo Savant, Holbrook, NY, USA) and analyzed, using a two-site enzyme immunoassay for PrRP as described previously (Matsumoto et al. 1999a). The two monoclonal antibodies used in this enzyme immunoassay detect common epitopes among rat, human and bovine PrRP20 (Matsumoto et al. 1999a) and can measure PrRP in these species (S Hinuma, unpublished data). By cloning an ovine PrRP cDNA, it was confirmed that the ovine PrRP20 sequence is identical to bovine PrRP20 (S Hinuma, unpublished data). As the amino acid sequence of PrRP20 is contained in PrRP31, this assay estimates total PrRP in the plasma. The sensitivity of the assay was $0 \cdot 11 \mathrm{pg} / \mathrm{ml}$ and the intra- and interassay coefficients of variation were $9 \cdot 5 \%$ and $11 \%$ respectively.

\section{Analysis}

As progesterone completely blocked the estradiol-induced prolactin surge, the P-block group was excluded from statistical analysis of the characteristics of the prolactin surge. As the prolactin surge had already started at the time blood sampling commenced in several animals, it was not possible to obtain basal secretion concentrations. Thus, the peak prolactin was taken as the maximum concentration during the surge. The time of the peak in prolactin secretion was also calculated. To obtain an estimate of duration, the period from when samples first exceeded the half-peak level to when samples fell below the half-peak level and remained below this level for at least $4 \mathrm{~h}$ was calculated. The peak, time of the peak and duration of the prolactin surge of the RU486 and control groups were analyzed by Student's $t$-test. Data from the PrRP studies were analyzed by repeated measures ANOVA with Tukey's post-hoc analysis. Significance was accepted at $P<0 \cdot 05$.

\section{Results}

In all ewes treated only with estradiol, there was a large surge in prolactin secretion (Figs 2 and 3). The continued 


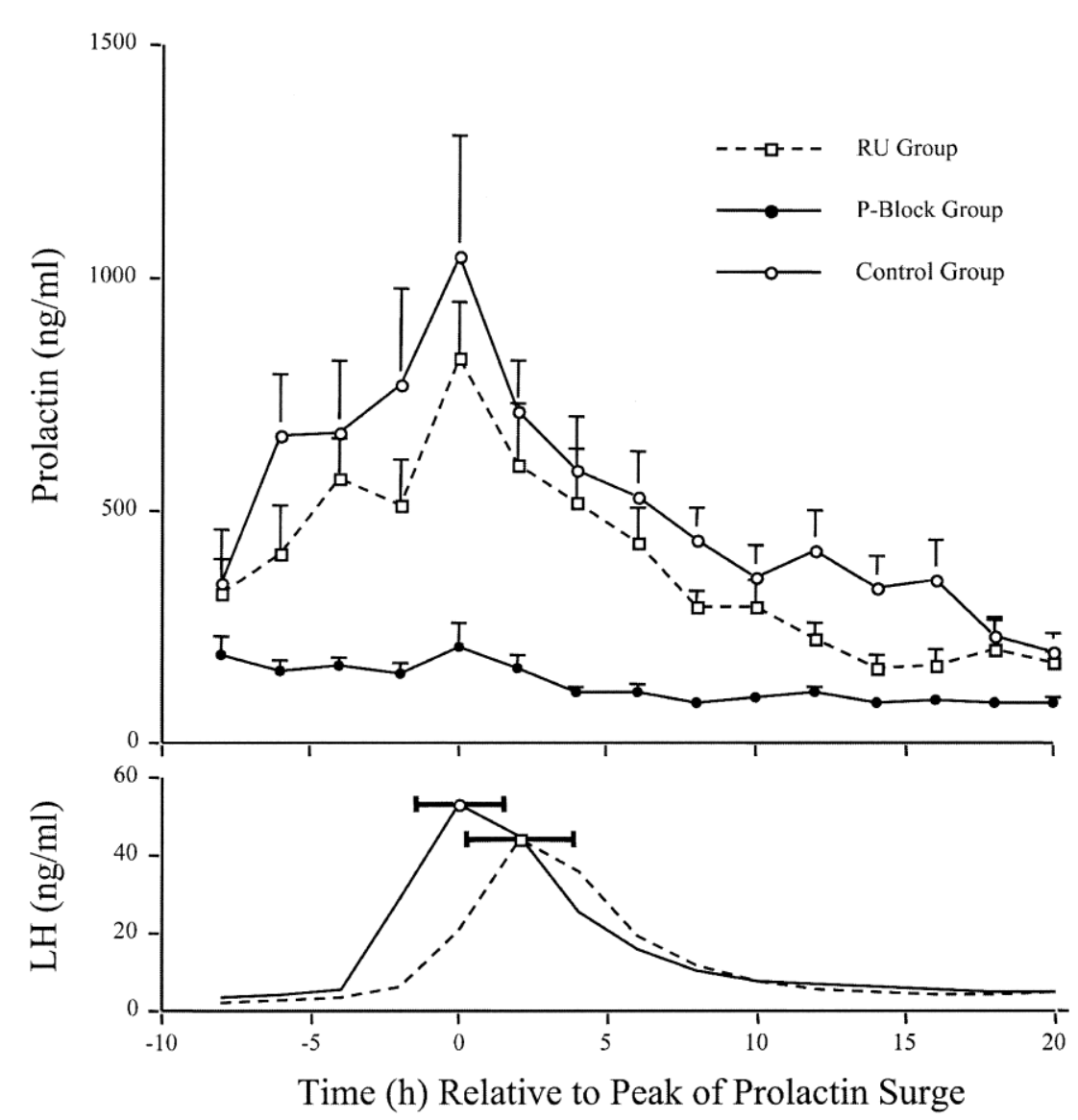

Figure 3 Prolactin concentrations (means \pm S.E.M.) expressed relative to the time of the peak in prolactin release. Estradiol induced a surge in prolactin $(\bigcirc)$. RU486 ( $\square$ ) completely overcame the progesterone-mediated blockade $(\mathbf{O})$ of the LH surge. For comparative purposes, LH data that were previously reported upon (Skinner et al. 1999) have been expressed relative to the time of peak prolactin and the error bar at the peak indicates the S.E.M. of the time of the peak in LH relative to the time of the peak in prolactin.

presence of progesterone inhibited the prolactin surge in all ewes and RU486 treatment entirely blocked this inhibitory effect of progesterone. There was no significant difference in the time of peak prolactin secretion after estradiol implant insertion between the control ewes $(16 \cdot 7 \pm 1 \cdot 4 \mathrm{~h})$ and those animals treated with RU486 $(19 \cdot 0 \pm 2 \cdot 2 \mathrm{~h})$. In addition, the timing of the peak of the prolactin surge, relative to the LH surge, was not significantly different in either the control or RU486 groups (Fig. 3). There was no significant difference in the peak concentration (control: $1047 \pm 253 \mathrm{ng} / \mathrm{ml}$; RU486: $827 \pm 118 \mathrm{ng} / \mathrm{ml}$ ) or the half-peak duration (control: $16 \cdot 3 \pm 2 \cdot 2 \mathrm{~h} ;$ RU486: $11 \cdot 2 \pm 1 \cdot 4 \mathrm{~h}$ ) of the prolactin surges. The LH data for these ewes have been reported previously (Skinner et al. 1999).

PrRP concentrations in CSF, jugular plasma and hypophyseal portal plasma were extremely low and were all near the detection limit of the assay. In contrast to prolactin concentrations in the jugular blood, PrRP concentrations in the CSF and jugular plasma were not affected by estradiol treatment (Table 1). Although PrRP levels in the hypophyseal portal blood were significantly $(P<0 \cdot 05)$ decreased by the end of the study, there was no relationship with prolactin levels, which showed a typical surge (Table 2).

Table 1 PrRP levels in the CSF and jugular blood, and jugular blood prolactin concentrations at specific time-points in the estradiol-induced prolactin surge. Values are means \pm S.E.M.

\begin{tabular}{|c|c|c|c|}
\hline & $\begin{array}{l}\text { Prolactin } \\
(\mathrm{ng} / \mathrm{ml})\end{array}$ & $\begin{array}{l}\text { CSF PrRP } \\
(\mathrm{fg} / \mathrm{ml})\end{array}$ & $\begin{array}{l}\text { Jugular PrRP } \\
(\mathrm{fg} / \mathrm{ml})\end{array}$ \\
\hline Pre-surge & $66 \cdot 6 \pm 9 \cdot 5^{a}$ & $212 \cdot 5 \pm 54 \cdot 7$ & $153 \cdot 9 \pm 12 \cdot 9$ \\
\hline Mid-surge & $377 \cdot 6 \pm 38 \cdot 6^{b}$ & $131 \cdot 2 \pm 17 \cdot 4$ & $151 \cdot 9 \pm 6 \cdot 6$ \\
\hline Late-surge & $141 \cdot 4 \pm 47 \cdot 3^{c}$ & $212 \cdot 9 \pm 96 \cdot 3$ & $172 \cdot 5 \pm 9 \cdot 7$ \\
\hline
\end{tabular}

Differing letters within a column indicate significant differences (ANOVA; $P<0 \cdot 05)$. 
Table 2 PrRP levels in the hypophyseal portal blood and jugular blood prolactin concentrations at specific time-points in the estradiol-induced prolactin surge. Values are means \pm S.E.M.

\begin{tabular}{|c|c|c|}
\hline & $\begin{array}{l}\text { Prolactin } \\
(\mathrm{ng} / \mathrm{ml})\end{array}$ & $\begin{array}{l}\text { Portal PrRP } \\
(\mathrm{fg} / \mathrm{ml})\end{array}$ \\
\hline Pre-surge & $42 \cdot 5 \pm 22 \cdot 4^{a}$ & $669 \cdot 9 \pm 77 \cdot 0^{a}$ \\
\hline Early-surge & $626 \cdot 8 \pm 110 \cdot 1^{b}$ & $706 \cdot 6 \pm 123 \cdot 4^{\mathrm{a}}$ \\
\hline Mid-surge & $822 \cdot 2 \pm 65 \cdot 7^{b}$ & $469 \cdot 4 \pm 111 \cdot 9^{\mathrm{ab}}$ \\
\hline Late-surge & $185 \cdot 0 \pm 22 \cdot 7^{\mathrm{c}}$ & $266 \cdot 0 \pm 41 \cdot 5^{b}$ \\
\hline
\end{tabular}

Differing letters within a column indicate significant differences (ANOVA; $P<0 \cdot 05)$.

\section{Discussion}

This study demonstrates that the estradiol-induced prolactin surge, like the LH surge, is blocked by progesterone and that this blockade is probably transduced through the nuclear progesterone receptor. This finding concurs with an earlier study in the rat, in which the inhibitory effect of progesterone on estradiol-induced prolactin secretion was overcome by RU486 (Brann et al. 1988). In addition, our study provides strong evidence that, in ewes, PrRP is not released into either the hypophyseal portal circulation or the CSF at the time of the prolactin surge. Thus, it is unlikely that PrRP contributes directly to the prolactin surge.

A concomitant surge in prolactin at the time of the $\mathrm{LH}$ surge has been observed in several species including humans (Djahanbakhch et al. 1984, Arbogast \& BenJonathan 1989, Campbell et al. 1990, Gonen \& Casper 1990). However, in contrast to the LH surge, few studies have been carried out on the prolactin surge in species apart from the rat. This paucity of information may be a result of earlier investigations that could find no physiological relevance for the prolactin surge (Buys et al. 1990) but more recent investigations suggest that it may be critical in causing full luteolysis of the corpus luteum from the preceding cycle (Gaytan et al. 1998, Bowen \& Keyes 1999).

The neuronal mechanisms involved in the generation of the prolactin surge are largely unknown and the present study provides compelling evidence that the recently identified PrRP (Hinuma et al. 1998) is not involved in the estradiol-induced prolactin surge in the ewe. Indeed, whether PrRP plays any physiological role in the release of prolactin is unclear. Using PrRP at doses $10^{4}$ to $10^{5}$ times the concentration we have detected in hypophyseal portal blood, some studies on the rat have shown that PrRP is able to stimulate prolactin secretion both in vitro (Hinuma et al. 1998, Tokita et al. 1999, Kawamata et al. 2000) and in vivo (Matsumoto et al. 1999b). Indeed, treatments with $1 \mathrm{nM}(3.6 \mu \mathrm{g})$ PrRP31 were ineffective in stimulating prolactin secretion from isolated rat pituitary cells (Hinuma et al. 1998, Tokita et al. 1999, Kawamata et al. 2000). Other recent studies have also implicated PrRP in the estradiol-induced prolactin surge of the rat (Matsumoto et al. 1999b, Hizume et al. 2000). In contrast, PrRP administered in vivo had no effect on prolactin secretion in both the rat (Jarry et al. 2000) and sheep (Curlewis et al. 2002). Although an extensive network of PrRP immunoreactive fibers has been described in the rat brain (Matsumoto et al. 1999b), PrRP fibers are not detected in the external zone of the median eminence (Maruyama et al. 1999, Morales et al. 2000). Moreover, a recent study employing push-pull perfusion in the rat median eminence/arcuate nucleus region found that, at the time of the LH surge, PrRP did not increase, whereas there was a significant increase in GnRH (Watanobe 2001). Taken together with the results from the present study, these data provide compelling evidence that in vivo PrRP is not secreted into the hypophyseal portal circulation and any putative role of this peptide in the physiological control of pituitary prolactin secretion may involve intra-hypothalamic neuronal circuits.

It is well known that dopamine potently inhibits prolactin release, and in both the rat (Bowen \& Keyes 1999) and sheep (Picazo et al. 2000), peripheral administration of bromocriptine, a dopamine $\mathrm{D}_{2}$ receptor agonist, abolishes the prolactin surge without affecting the $\mathrm{LH}$ surge. Although this may suggest that a reduction in dopamine release is permissive for the prolactin surge, it has not been established, to our knowledge, whether dopamine secretion in the hypophyseal portal blood decreases at the time of the estradiol-induced prolactin surge. Moreover, the precise role of dopamine in the ovine $\mathrm{LH}$ /prolactin surges remains unclear as there is evidence that dopamine levels in the ventromedial hypothalamus (VMH) are elevated prior to these surges (Anderson et al. 2001). Administration of $\alpha$-methyl-p-tyrosine ( $\alpha \mathrm{MPT})$, a catecholamine synthesis inhibitor, was shown to delay and attenuate the LH but not the prolactin surge (Anderson et al. 2001). However, as these authors note, infusion of the $\alpha \mathrm{MPT}$ commenced $2 \mathrm{~h}$ before the onset of the prolactin surge, which may have been too late to influence the prolactin surge. Moreover, data from rats suggest that the VMH does play a role in estradiol-induced prolactin secretion (Pan \& Gala 1985). In the context of our hypothesis that the LH and prolactin surge-generating systems may share common steroid-sensitive neuronal pathways, then this $\mathrm{VMH}$ population could be downstream of the initial common neuronal target.

Thyrotropin-releasing hormone is known to stimulate prolactin secretion and thus it is plausible to speculate that increased thyrotropin-releasing hormone release at the time of the surge may contribute to the prolactin surge. Studies in the rat suggest that this peptide does not play a pivotal role in the proestrous prolactin surge (Horn et al. 1985). However, it is noteworthy that a preovulatory thyroid-stimulating hormone surge has been reported in the hamster (Howes et al. 1991). The suprachiasmatic nucleus, which controls circadian rhythms, plays a critical 
role in the timing of the $\mathrm{LH}$ and prolactin surges in the rat (Harney et al. 1996). In this species, suprachiasmatic nucleus vasoactive intestinal peptide has been implicated in the prolactin surge (van der Beek et al. 1998, Palm et al. 2001). There is no evidence for a role of the suprachiasmatic nucleus in the generation of the preovulatory LH or prolactin surges in the ewe.

It is possible that estradiol acts directly on lactotropes in the pituitary gland to influence prolactin secretion (Scully et al. 1997). In humans, up to $50 \%$ of these pituitary cells co-localize with estradiol receptor $\alpha$ (Friend et al. 1994). However, in sheep, only 15\% of lactotropes have been reported to express estradiol receptor $\alpha$ and, in contrast to gonadotropes, there was no estrous cycle variation in the percentage of lactotropes expressing estradiol receptor $\alpha$ (Tobin et al. 2001). It is also plausible that pituitary paracrine mechanisms within the pituitary may play a role, at least in part, in the prolactin surge (Ganong 1993). Earlier studies in the rat have reported that in response to GnRH, gonadotropes may release both LH and angiotensin II (Deschepper et al. 1986, Ganong et al. 1989). Several investigators have shown that angiotensin II is able to elicit the secretion of prolactin in vitro (Aguilera et al. 1982, Schramme \& Denef 1983, Ganong 1989). It is plausible to speculate, therefore, that the prolactin surge is induced indirectly by GnRH but limited experimental data are equivocal (Ganong 1993). To our knowledge, no studies have determined whether angiotensin II is present in ovine gonadotropes and the relationship between this peptide, GnRH and prolactin release warrants further investigation.

In summary, this study shows that, as for LH, progesterone blocks the estradiol-induced prolactin surge and that this blockade is overcome by RU486, suggesting that the nuclear progesterone receptor mediates this blockade. Furthermore, our study has shown that PrRP is not released into hypophyseal portal circulation or CSF, providing compelling evidence that this peptide is not involved in the estradiol-induced prolactin surge in the ewe. Whether interneuronal systems involved in generating the GnRH surge regulate the prolactin surge and/or whether a separate intra-pituitary system is involved remains to be determined.

\section{Acknowledgements}

We are grateful to Drs Shuji Hinuma, Hirokazu Matsumoto and Shoji Fukusumi of the Takeda Pharmaceutical Research Division for analyzing the CSF, jugular and portal blood samples for PrRP.

\section{References}

Aguilera G, Hyde CL \& Catt KJ 1982 Angiotensin II receptors and prolactin release in pituitary lactotrophs. Endocrinology 111 1045-1050.
Anderson ST, Walsh JP, Tillet Y, Clarke IJ \& Curlewis JD 2001 Dopaminergic input to the ventromedial hypothalamus facilitates the oestrogen-induced luteinizing hormone surge in ewes. Neuroendocrinology 73 91-101.

Arbogast LA \& Ben-Jonathan N 1988 The preovulatory prolactin surge: an evaluation of the role of dopamine. Endocrinology $\mathbf{1 2 3}$ 2690-2695

Arbogast LA \& Ben-Jonathan N 1989 Tyrosine hydroxylase in the stalk-median eminence and posterior pituitary is inactivated only during the plateau phase of the preovulatory prolactin surge. Endocrinology 125 667-674.

van der Beek EM, Swarts HJM \& Wiegant VM 1998 Central administration of antiserum to vasoactive intestinal peptide delays and reduces luteinizing hormone and prolactin surges in ovariectomized, estrogen-treated rats. Neuroendocrinology 69 227-237.

Bowen JM \& Keyes PL 1999 The proestrous prolactin surge is not the sole initiator of regressive changes in corpora lutea of normally cycling rats. Biology of Reproduction 61 1208-1215.

Bowen JM, Telleria CM, Towns R \& Keyes PL 2000 Downregulation of long-form prolactin receptor mRNA during prolactin-induced luteal regression. European Journal of Endocrinology $143285-292$.

Brann DW, Rao IM \& Mahesh VB 1988 Antagonism of estrogen-induced prolactin release by progesterone. Biology of Reproduction 39 1067-1073.

Buys N, Peeters R, de Clerck B, van Isterdael J, Kühn ER \& Decuypere E 1990 Seasonal variations in prolactin, growth hormone and thyroid hormones and the prolactin surge at ovulation do not affect litter size of ewes during pregnancy in the oestrous or the anoestrous season. Journal of Reproduction and Fertility 90 47-53.

Campbell B, Mann G, McNeilly A \& Baird D 1990 The pattern of ovarian inhibin, estradiol, and androstenedione secretion during the estrous cycle of the ewe. Endocrinology 127 227-235.

Caraty A \& Locatelli A 1988 Effect of time after castration on secretion of LHRH and LH in the ram. Journal of Reproduction and Fertility 82 263-269.

Caraty A, Fabre-Nys C, Delaleu B, Locatelli A, Bruneau G, Karsch FJ \& Herbison A 1998 Evidence that the mediobasal hypothalamus is the primary site of action of estradiol in inducing the preovulatory gonadotropin releasing hormone surge in the ewe. Endocrinology 139 1752-1760.

Curlewis JD, Kusters DH, Barclay JL \& Anderson ST 2002 Prolactin-releasing peptide in the ewe: cDNA cloning, mRNA distribution and effects on prolactin secretion in vitro and in vivo. Journal of Endocrinology 174 45-53.

Deschepper CF, Crumrine DA \& Ganong WF 1986 Evidence that the gonadotrophs are the likely site of production of angiotensin II in the anterior pituitary of the rat. Endocrinology $11936-43$.

Djahanbakhch O, McNeilly AS, Warner PM, Swanston IA \& Baird DT 1984 Changes in plasma levels of prolactin, in relation to those of FSH, oestradiol, androstenedione and progesterone around the preovulatory surge of LH in women. Endocrinology 110 1292-1299.

Dufourny L \& Skinner DC 2002 Progesterone receptor, estrogen receptor a and the type II glucocorticoid receptor are coexpressed in the same neurons of the ovine preoptic area and arcuate nucleus: a triple immunolabeling study. Biology of Reproduction 67 1605-1612.

Fink G 1988 Oestrogen and progesterone interactions in the control of gonadotrophin and prolactin secretion. Journal of Steroid Biochemistry 30 169-178.

Friend KE, Chiou YK, Lopes MB, Laws ER Jr, Hughes KM \& Shupnik MA 1994 Estrogen receptor expression in human pituitary: correlation with immunohistochemistry in normal tissue, and immunohistochemistry and morphology in macroadenomas. Journal of Clinical Endocrinology and Metabolism 78 1497-1504.

Ganong WF 1989 Angiotensin II in the brain and pituitary: contrasting roles in the regulation of adenohypophyseal secretion. Hormone Research 31 24-31. 
Ganong WF 1993 Blood, pituitary, and brain renin-angiotensin systems and regulation of secretion of anterior pituitary gland. Frontiers in Neuroendocrinology 14 233-249.

Ganong WF, Deschepper CF, Steele MK \& Intebi A 1989 Renin-angiotensin system in the anterior pituitary of the rat. American Journal of Hypertension 2 320-322.

Gaytan F, Bellido C, Morales C \& Sanchez-Criado JE 1998 Both prolactin and progesterone in proestrus are necessary for the induction of apoptosis in the regressing corpus luteum of the rat. Biology of Reproduction 59 1200-1206.

Gaytan F, Morales C, Bellido C, Aguilar R, Millan Y, Martin De Las Mulas J \& Sanchez-Criado JE 2000 Progesterone on an oestrogen background enhances prolactin-induced apoptosis in regressing corpora lutea in the cyclic rat: possible involvement of luteal endothelial cell progesterone receptors. Journal of Endocrinology 165 715-724.

Gonen Y \& Casper R 1990 Transient hyperprolactinemia is associated with a midcycle luteinizing hormone surge. Fertility and Sterility $\mathbf{5 4}$ 936-938.

Goodman RL, Legan SJ, Ryan KD, Foster DL \& Karsch FJ 1981 Importance of variations in behavioural and feedback actions of oestradiol to the control of seasonal breeding in the ewe. Journal of Endocrinology 89 229-240.

Harney JP, Scarbrough K, Rosewell KL \& Wise PM 1996 In vivo antisense antagonism of vasoactive intestinal peptide in the suprachiasmatic nuclei causes aging-like changes in the estradiol-induced luteinizing hormone and prolactin surges. Endocrinology 137 3696-3701.

Herbison AE, Robinson JE \& Skinner DC 1993 Distribution of estrogen receptor-immunoreactive cells in the preoptic area of the ewe: co-localization with glutamic acid decarboxylase but not luteinizing hormone-releasing hormone. Neuroendocrinology $\mathbf{5 7}$ 751-759.

Hinuma S, Habata Y, Fujii R, Kawamata Y, Hosoya M, Fukusumi S, Kitada C, Masuo Y, Asano T, Matsumoto H, Sekiguchi M, Kurokawa T, Nishimura O, Onda H \& Fujino M 1998 A prolactin-releasing peptide in the brain. Nature 393 272-276.

Hizume T, Watanobe H, Yoneda M, Suda T \& Schioth HB 2000 Involvement of prolactin-releasing peptide in the preovulatory luteinizing hormone and prolactin surges in the rat. Biochemical and Biophysical Research Communications 279 35-39.

Horn AM, Fraser HM \& Fink G 1985 Effects of antiserum to thyrotrophin-releasing hormone on the concentrations of plasma prolactin, thyrotrophin and $\mathrm{LH}$ in the pro-oestrous rat. Journal of Endocrinology 104 205-209.

Howes K, Menendez-Pelaez A, Reiter R, Vaughan M, Hensel C \& Vaughan G 1991 Serum luteinizing hormone, prolactin, and thyrotropin and their pituitary subunit mRNA levels during proestrus in the Syrian hamster. Neuroendocrinology 54 629-634.

Jarry H, Heuer H, Schomburg L \& Bauer K 2000 Prolactin-releasing peptides do not stimulate prolactin release in vivo. Neuroendocrinology 71 262-267.

Kann G 1971 Dosage radioimmunologique de la prolactine plasmatique chez les ovins. Comptes Rendus de l'Académie des Sciences 272 2808-2811.

Kasa-Vubu JZ, Dahl GE, Evans NP, Thrun LA, Moenter SM, Padmanabhan V \& Karsch FJ 1992 Progesterone blocks the estradiol-induced gonadotropin discharge in the ewe by inhibiting the surge of gonadotropin-releasing hormone. Endocrinology 131 208-212.

Kawamata Y, Fujii R, Fukusumi S, Habata Y, Hosoya M, Hinuma S, Kitada C, Onda H, Nishimura O \& Fujino M 2000 Analyses for susceptibility of rat anterior pituitary cells to prolactin-releasing peptide. Endocrine 12 215-221.

Lehman MN \& Karsch FJ 1993 Do gonadotropin-releasing hormone, tyrosine hydroxylase-, and $\beta$-endorphin-immunoreactive neurons contain estrogen receptors? A double-label immunocytochemical study in the Suffolk ewe. Endocrinology 133 887-895.
Maruyama M, Matsumoto H, Fukiwara K, Kitada C, Hinuma S, Onda H, Fujino M \& Inoue K 1999 Immunocytochemical localization of prolactin-releasing peptide in the rat brain. Endocrinology 140 2326-2333.

Matsumoto H, Murakami Y, Horikoshi Y, Noguchi J, Habata Y, Kitada C, Hinuma S, Onda H \& Fujino M 1999a Distribution and characterization of immunoreactive prolactin-releasing peptide (PrRP) in rat tissue and plasma. Biochemical and Biophysical Research Communications 257 264-268.

Matsumoto H, Noguchi J, Horikoshi Y, Kawamata Y, Kitada C, Hinuma S, Onda H, Nishimura O \& Fujino M 19996 Stimulation of prolactin release by prolactin-releasing peptide in rats. Biochemical and Biophysical Research Communications 259 321-324.

Morales T, Hinuma S \& Sawchenko PE 2000 Prolactin-releasing peptide is expressed in afferents to the endocrine hypothalamus, but not in neurosecretory neurones. Journal of Neuroendocrinology 12 131-140.

Palm IF, van der Beek EM, Swarts HJ, van der Vliet J, Wiegant VM, Buijs RM \& Kalsbeek A 2001 Control of the estradiol-induced prolactin surge by the suprachiasmatic nucleus. Endocrinology 142 2296-2302.

Pan JT \& Gala RR 1985 Central nervous system regions involved in the estrogen-induced afternoon prolactin surge. II. Implantation studies. Endocrinology 117 388-395.

Picazo RA, Gonzalez De Bulnes A, Gomez Brunet A, del Campo A, Granados B, Tresguerres J \& Lopez Sebastian A 2000 Effects of bromocriptine administration during the follicular phase of the oestrous cycle on prolactin and gonadotrophin secretion and follicular dynamics in merino monovular ewes. Journal of Reproduction and Fertility 120 177-186.

Richter TA, Robinson JE \& Evans NP 2002 Progesterone blocks the estradiol-stimulated luteinizing hormone surge by disrupting activation in response to a stimulatory estradiol signal in the ewe. Biology of Reproduction 67 119-125.

Samson WK, Resch ZT, Murphy TC \& Chang JK 1998 Gender-biased activity of the novel prolactin releasing peptides: comparison with thyrotropin releasing hormone reveals only pharmacologic effects. Endocrine 9 289-291.

Schramme C \& Denef C 1983 Stimulation of prolactin release by angiotensin II in superfused rat anterior pituitary cell aggregates. Neuroendocrinology 36 483-485.

Scully KM, Gleiberman AS, Lindzey J, Lubahn DB, Korach KS \& Rosenfeld MG 1997 Role of estrogen receptor- $\alpha$ in the anterior pituitary gland. Molecular Endocrinology 11 674-681.

Seal LJ, Small CJ, Kim MS, Stanley SA, Taheri S, Ghatei MA \& Bloom SR 2000 Prolactin releasing peptide (PrRP) stimulates luteinizing hormone (LH) and follicle stimulating hormone (FSH) via a hypothalamic mechanism in male rats. Endocrinology 141 1909-1912.

Seal LJ, Small CJ, Dhillo WS, Kennedy AR, Ghatei MA \& Bloom SR 2002 Prolactin-releasing peptide releases corticotropin-releasing hormone and increases plasma adrenocorticotropin via the paraventricular nucleus of the hypothalamus. Neuroendocrinology 76 70-78.

Skinner DC, Malpaux B, Delaleu B \& Caraty A 1995 Luteinizing hormone (LH)-releasing hormone in third ventricular cerebrospinal fluid of the ewe: correlation with $\mathrm{LH}$ pulses and the LH surge. Endocrinology 136 3230-3237.

Skinner DC, Caraty A, Malpaux B \& Evans NP 1997 Simultaneous measurement of gonadotropin-releasing hormone in the third ventricular cerebrospinal fluid and hypophyseal portal blood of the ewe. Endocrinology 138 4699-4704.

Skinner DC, Evans NP, Delaleu B, Goodman RL, Bouchard P \& Caraty A 1998 The negative feedback actions of progesterone on gonadotropin-releasing hormone secretion are transduced by the classical progesterone receptor. PNAS 95 10978-10983. 
Skinner DC, Bouchard P \& Caraty A 1999 The progesterone blockade of the LH surge is overcome by RU486. Journal of Neuroendocrinology 11 637-641.

Tobin VA, Pompolo S \& Clarke IJ 2001 The percentage of pituitary gonadotropes with immunoreactive oestradiol receptors increases in the follicular phase of the ovine oestrous cycle. Journal of

Neuroendocrinology 13 846-854.

Tokita R, Nakata T, Katsumata H, Konishi S, Onodera H, Imaki J \& Minami S 1999 Prolactin secretion in response to prolactin-releasing peptide and the expression of the prolactin-releasing peptide gene in the medulla oblongata are estrogen dependent in rats. Neuroscience Letters 276 103-106.
Watanobe H 2001 In vivo release of prolactin-releasing peptide in rat hypothalamus in association with luteinizing hormone and prolactin surges. Neuroendocrinology 74 359-366.

Received 11 February 2003

Accepted 13 March 2003

Made available online as an Accepted Preprint 17 March 2003 